\title{
The suitability of disaster loss databases to measure loss and damage from climate change
}

\author{
Melanie Gall \\ Hazards and Vulnerability Research Institute, \\ Department of Geography, \\ University of South Carolina, \\ Columbia, SC 29210, USA \\ Email: melanie.gall@sc.edu
}

\begin{abstract}
This paper explores the suitability of disaster loss databases for documenting impacts of climate change particularly those related to extreme weather and slow onset events. The goal is to clarify the utility, quality, and relevance of disaster loss metrics in the context of climate-sensitive hazards such as floods, tropical cyclones, droughts, and so forth. Although, disaster loss databases hold great potential for assessing some of the impacts from climate change, several modifications are required to enhance the utility of existing disaster loss databases, primarily in regard to data availability and quality. In order to effectively utilise disaster loss databases, loss metrics and hazard classifications should be broadened, time horizons for loss estimation expanded as well as loss estimation techniques improved along with a coordinated development and implementation of data and database standards.
\end{abstract}

Keywords: extreme event; climate change impacts; natural hazards; loss and damage; measuring losses; disaster loss database.

Reference to this paper should be made as follows: Gall, M. (2015) 'The suitability of disaster loss databases to measure loss and damage from climate change', Int. J. Global Warming, Vol. 8, No. 2, pp.170-190.

Biographical notes: Melanie Gall is a Research Assistant Professor in the Hazards and Vulnerability Research Institute and IRDR International Centre of Excellence on Vulnerability and Resilience Metrics at the University of South Carolina. She is a Hazards Geographer and Certified Floodplain Manager (CFM) with expertise in the quantification of social vulnerability, hazard mitigation planning, geospatial analytics, and impact assessments.

\section{Introduction}

Climate adaptation is gaining greater prominence due to the global community's inability to curb greenhouse gas emissions, which have now surpassed a carbon dioxide concentration of 400 ppm (US Department of Commerce, 2014). But climate adaptation is not limitless (Adger et al., 2008). Finite resources and technological capacity restrict the ability for incremental and more so transformative adaptation in social systems, primarily in developing countries (Kates et al., 2012; Moser and Ekstrom, 2010). With the realisation of limits to climate adaptation, defined as "a point at which an actor can no longer secure valued objectives from intolerable risk through adaptive action" [Dow 
et al., (2013), p.306], developing countries have advocated for the need to recuperate adaptation costs and implement risk transfer mechanisms (Morgan and Waskow, 2013) 2013).

This advocacy led the parties of the United National Framework Convention on Climate Change (UNFCCC) to adopt a work program on loss and damage at the climate conference in Cancun in 2010 (COP16) with the intent of exploring data and information requirements as well as data gaps for assessing the impacts from climate change (UNFCCC, 2011). At its 17 session in Durban in 2011, the conference of parties (COP17) established three thematic research areas on the topic of loss and damage from climate change. Guiding questions within thematic area I (assessing the risk of loss and damage associated with the adverse effects of climate change and the current knowledge on the same) were as following: What are the data and information requirements for assessing impacts and climate risk, at different levels and for a broad range of sectors and ecosystems? What data are available and where are the gaps? What methods and tools are available for risk assessment, including their requirements, strengths and weaknesses, and can they address social and environmental impacts? What are the capacity needs for applying risk assessment methods on the ground, including for facilitating their application in developing countries? How can the results of risk assessments be optimally formulated in order to support decision-making? And what are the desired methods for presenting the results of risk assessment exercises so that they drive decision-making? (UNFCCC, 2012a).

This paper responds to the first three questions by investigating the suitability of disaster loss databases for capturing the impact of extreme weather events and slow onset events. The purpose of this paper is to clarify the utility, quality, and relevance of disaster loss metrics in the context of climate-sensitive impacts. Only data and databases related to climate-sensitive hazards are included in this discussion. The following questions frame the suitability analysis:

1 Are disaster loss databases effective in measuring the impact from extreme weather events?

2 Are loss and damage of slow onset events captured in disaster loss databases?

3 How can existing disaster loss databases be improved to document loss and damage for both extreme weather events and slow onset events?

\section{Background}

\subsection{What is loss and damage?}

According to the UNFCCC's working definition, loss and damage are "the actual and/or potential manifestation of impacts associated with climate change in developing countries that negatively affect human and natural systems" with loss being identified as "the negative impacts in relation to which reparation or restoration is impossible" and damage as "negative impacts in relation to which reparation or restoration is possible" [UNFCCC, (2012b), p.3]. This separation between reversible and irreversible losses is a new concept to the disaster risk management community, which tends to use the terms 'loss', 'damage', 'cost' and 'impact' often interchangeably despite nuanced and disciplinary- 
specific interpretations of each of them. The engineering field, for example, tends to use the term 'damage' rather than loss to refer to the destruction of buildings and infrastructure. The term loss is most frequently applied to quantifiable and universally accepted units such as number of fatalities or currency (NRC, 1999) - again without distinguishing between reversible and irreversible impacts. In disaster risk management and therefore disaster loss databases, loss (or damage for that matter) encompasses the entire spectrum of adverse effects of extreme events including economic and non-economic, tangible and intangible, as well as reversible and irreversible impacts such as fatalities, destruction of infrastructure, homes, and crops, contamination of drinking water, or habitat loss (Below et al., 2009).

Traditionally losses as well as damage are classified into direct and indirect losses/damage (Cochrane, 2004). Any loss caused by direct physical harm from the hazard, such as a collapsed building, destroyed crops or a drowning death, is considered a direct loss. Any subsequent effect triggered by the physical destruction classifies as an indirect loss. This includes, for example, lost remittances, lost time in school, polluted drinking water, or lost income from business closures. Indirect losses are sometimes also called intangible losses or higher-order effects (Rose, 2004). It is important to note that direct and indirect losses are not exclusively tied to economic aspects of a disaster. Although a loss is a quantifiable measure and therefore frequently reduced to monetary and subsequently economic terms, it is equally applicable to losses in the social, cultural, or environmental domain (NRC, 1999). The loss of mangroves due to a tropical cyclone or sea-level rise, for example, is a direct environmental loss. In order to measure the loss, it is necessary to express it in a standard unit - such as monetary terms (e.g., lost environmental services), acreage, or similar. This paper adopts the traditional definitions of direct and indirect losses. The term 'loss and damage' used only in the context of climate change and should be interpreted consistent with the UNFCCC definition provided above.

Another significant difference between UNFCCC's definition of loss and damage and its usage in the disaster risk management community is the fact that the latter views disaster losses are materialised losses - not potential losses. So-called avoided losses meaning losses that did not materialise due to investments and smart risk management choices are generally referred to as costs (Gall et al., 2011). Costs, however, are generally not captured and documented in disaster loss databases. Similar is true for risk reduction investments that go beyond reconstruction to improve community resilience and climate change adaptation.

The insurance industry generally differentiates disaster impacts solely in terms of insured and uninsured losses without further distinguishing between direct or indirect, costs or damage in disaster loss databases (Smolka, 2006). Classifying losses into direct and indirect components is beyond the scope of insurance loss databases and in many cases difficult to achieve since there is not a one-to-one relationship between insured and direct or uninsured and indirect losses. In fact, insured losses (as well as uninsured losses) can have both direct as well as indirect components. For example, business interruption is generally classified as an indirect loss while it can also be an insured loss. This makes it very challenging to separate insured losses further into direct and indirect losses.

In sum, the UNFCCC definition of loss and damage is currently not compatible with established loss/damage meanings and categories in the disaster risk community, which creates challenges regarding a shared vocabulary and knowledge-base as well as 
meaningful interruptions of the data contained in disaster loss databases as discussed in the following.

\subsection{Disaster risk management and climate adaptation}

Assessing the impacts from natural hazards used to be a topic that almost exclusively concerned only the disaster risk community and the insurance industry. Escalating losses from floods, tropical cyclones, droughts, and so forth, were generally attributed to the changes in the social system meaning the continued placement of people and assets in high-risk zones (IPCC, 2012). In recent years, however, both the scientific as well as professional community have raised concerns in regard to the role and degree of climate change in this context (Jagger et al., 2011; Munich Re, 2009). This is not surprising given that climate change-induced shifts in rainfall and temperature patterns along with sealevel rise are forecast to worsen the impacts of climate-sensitive hazards such as tropical cyclones or droughts resulting in more extreme weather events in areas accustomed and unaccustomed to them (Nicholls et al., 1999; Emanuel, 2005; IPCC, 2012).

Unlike carbon dioxide concentrations though, disaster losses are not direct, physical indicators of climate change. Instead they are a complex product of the magnitude of the extreme event as well as a community's ability to prepare for, respond to and recover from it (Oliver-Smith et al., 2012). For example, disaster losses can simply increase due to an increase of assets at risk without an increase in event severity or forcing by climate change (Pielke et al., 2005).

The relationship between event magnitude and resilience, meaning "the ability of a system, community, or society exposed to hazards to resist, absorb, accommodate to and recover from the effects" (UNISDR, 2009; Miller et al., 2010; Janssen and Ostrom, 2006) becomes apparent in the different loss patterns that developed and developing countries experience. Developing countries suffer far greater death tolls than developed countries (Toya and Skidmore, 2007). The absence of effective disaster risk management and resources for disaster preparedness at national and sub-national government levels, i.e., barriers to risk management, combined with limited resilience at the individual level, create highly vulnerable environments - especially in least developed countries (Adger, 2006; Cutter et al., 2010).

Quantifying losses is therefore not solely an assessment of the harm done by a disaster; it is also an evaluation of risk management strategies and their effectiveness: how much loss is acceptable? Where and how much investment is needed to reduce losses? Increasing amounts of loss, given the same event magnitude, can be interpreted as insufficient and inadequate disaster risk management or maladaptation in a climate context; lower loss in highly vulnerable locations, on the other hand are testimony to effective risk management strategies (or successfully climate adaptation).

When losses are no longer acceptable and risk levels are too high, communities tend to start implementing risk reduction strategies framed by their political, economic, social, environmental and cultural resources and capacities. Risk levels at which protective actions are taken vary from community to community, hereby indicating a society's level of risk tolerance (Klinke and Renn, 2002; Hall et al., 2012). When or when not to engage in risk reduction (adaptation) activities could possibly serve as a social system threshold in regard to climate adaptation.

Again, disaster losses are a multi-dimensional measure capturing: 
a the interaction between the environment and society

b acommunity's to environmental shocks

c a society's risk tolerance.

This makes disaster losses an appealing indicator for tracking both progress as well as barriers in climate adaptation. However, the suitability of existing disaster loss metrics to capture loss and damage from climate change or measure progress in climate adaptation have neither been explore qualitatively nor quantitatively. This paper offers a qualitative analysis with a particular focus on the ability to capture the impacts from extreme events and slow onset events.

\section{Measuring the impacts from extreme events}

\subsection{National and international disaster loss databases}

Disaster loss databases collect, consolidate, and organise loss data in a central repository. By spatially and temporally tracking disaster losses, these databases support the evaluation of risk reduction efforts, community resilience and benchmarking of progress. Similar to setting goals in the reduction of greenhouse gases, a community can, for example, set benchmarks and goals for loss reduction such as a reduction of $x$ percent of monetary losses and/or fatalities over $y$ years. As such, disaster loss databases represent an essential planning tool to:

a identify high-risk hazards

b identify highly vulnerable areas

c prioritise disaster risk reduction actions

d' establish a baseline to track risk management progress

e establish a baseline to track progress in community resilience

$\mathrm{f}$ evaluate the effectiveness of risk reduction measures

g conduct empirical research on climate change attribution of natural hazards (Glavovic and Smith, 2014).

At the international level, there are two, publicly accessible disaster loss databases with global coverage (Table 1). The most widely known is EM-DAT, which was established in 1973 by the Center for Research on the Epidemiology of Disasters (CRED) at the Catholic University of Louvain, Brussels. Its long-standing experience with loss data collection has made CRED, along with re-insurance companies such as Munich Re and Swiss Re, a thought leader on data needs and quality standards for disaster loss data. The EM-DAT database contains over 20,000 records with some records dating back to 1900 (IRDR, 2014). The database focuses on major events and includes only events that caused either ten fatalities, 100 people affected, or required a declaration of state of emergency or call for international assistance (CRED, 2012). 
The suitability of disaster loss databases to measure loss and damage

Table 1 Examples of database structures of select global and national databases

\begin{tabular}{|c|c|c|c|c|}
\hline Attributes & $E M-D A T$ & NatCatSERVICE & GLIDE & DesInventar \\
\hline $\begin{array}{l}\text { Spatial } \\
\text { coverage }\end{array}$ & Global & Global & Global & National \\
\hline $\begin{array}{l}\text { Spatial } \\
\text { resolution }\end{array}$ & Country & Country & Country & $\begin{array}{l}\text { County, } \\
\text { municipality }\end{array}$ \\
\hline $\begin{array}{l}\text { Temporal } \\
\text { coverage }\end{array}$ & 1900-present & 79 AD-present & 1930-present & $\begin{array}{c}\text { Varies by country, } \\
\text { more than } 30 \\
\text { countries operate } \\
\text { DesInventar } \\
\text { databasess }\end{array}$ \\
\hline $\begin{array}{l}\text { Number of } \\
\text { records }\end{array}$ & $>20,000$ & $>33,000$ & $>5,000$ & Varies by country \\
\hline $\begin{array}{l}\text { Recording } \\
\text { thresholds }\end{array}$ & $\begin{array}{c}\geq 10 \text { fatalities, } \\
\geq 100 \text { affected, } \\
\text { declaration of state } \\
\text { of emergency, or } \\
\text { call for } \\
\text { international } \\
\text { assistance }\end{array}$ & & $\begin{array}{l}\geq 10 \text { fatalities, } \\
\geq 100 \text { affected, } \\
\text { declaration of } \\
\text { state of } \\
\text { emergency, or } \\
\text { call for } \\
\text { international } \\
\text { assistance }\end{array}$ & $\begin{array}{l}\geq 1 \text { human loss or } \\
\geq \$ 1 \text { in economic } \\
\text { loss }\end{array}$ \\
\hline Data sources & $\begin{array}{l}\text { UN agencies, } \\
\text { IFRC, World } \\
\text { Bank, reinsurers, } \\
\text { press, news } \\
\text { agencies, etc. }\end{array}$ & $\begin{array}{l}\text { Property claims } \\
\text { service, insurance } \\
\text { clients, UN } \\
\text { agencies, World } \\
\text { Bank, press, } \\
\text { academia, etc. }\end{array}$ & $\begin{array}{l}\text { UN agencies, } \\
\text { IFRC, World } \\
\text { Bank, reinsurers, } \\
\text { press, news } \\
\text { agencies, etc. }\end{array}$ & $\begin{array}{c}\text { UN agencies, } \\
\text { weather services, } \\
\text { geological } \\
\text { services, press, } \\
\text { etc. }\end{array}$ \\
\hline Audience & $\begin{array}{l}\text { Humanitarian } \\
\text { community, } \\
\text { academia }\end{array}$ & $\begin{array}{l}\text { General public, } \\
\text { insurance industry }\end{array}$ & $\begin{array}{l}\text { Loss database } \\
\text { operators }\end{array}$ & $\begin{array}{c}\text { Emergency } \\
\text { management, } \\
\text { hazard mitigation } \\
\text { planning, } \\
\text { academia }\end{array}$ \\
\hline $\begin{array}{l}\text { Download } \\
\text { URL }\end{array}$ & $\begin{array}{l}\text { http://www.emdat. } \\
\text { be }\end{array}$ & & Glidenumber.net & $\begin{array}{l}\text { http://www.desinv } \\
\text { entar.org }\end{array}$ \\
\hline Owner & $\begin{array}{c}\text { Centre for } \\
\text { Research on the } \\
\text { Epidemiology of } \\
\text { Disasters, } \\
\text { Université } \\
\text { Catholique de } \\
\text { Louvain, Belgium }\end{array}$ & $\begin{array}{l}\text { Munich Re, } \\
\text { Germany }\end{array}$ & $\begin{array}{l}\text { Asian Disaster } \\
\text { Reduction } \\
\text { Center, Japan }\end{array}$ & Varies by country \\
\hline Killed & $\mathrm{x}$ & & & $\mathrm{x}$ \\
\hline Injured & $\mathrm{x}$ & $\mathrm{x}$ & & $\mathrm{x}$ \\
\hline
\end{tabular}

Source: Adapted from IRDR (2014) 
Table 1 Examples of database structures of select global and national databases (continued)

\begin{tabular}{|c|c|c|c|c|}
\hline Attributes & $E M-D A T$ & NatCatSERVICE & GLIDE & DesInventar \\
\hline Missing & & $\mathrm{x}$ & & $\mathrm{x}$ \\
\hline Homeless & $\mathrm{x}$ & & & $\mathrm{x}$ \\
\hline Affected & $\mathrm{x}$ & $\mathrm{x}$ & & \\
\hline Evacuated & & $\mathrm{x}$ & & $\mathrm{x}$ \\
\hline Relocated & & & & $\mathrm{x}$ \\
\hline Displaced & & $\mathrm{x}$ & & \\
\hline Property loss & $\mathrm{x}$ & & & \\
\hline Crop loss & $\mathrm{x}$ & & & \\
\hline $\begin{array}{l}\text { Environmental } \\
\text { loss }\end{array}$ & $\mathrm{x}$ & & & \\
\hline Insured loss & & $\mathrm{x}$ & & \\
\hline $\begin{array}{l}\text { Aggregate } \\
\text { economic loss }\end{array}$ & $\mathrm{x}$ & $\mathrm{x}$ & & $\mathrm{x}$ \\
\hline $\begin{array}{l}\text { Infrastructure } \\
\text { damage }\end{array}$ & $\mathrm{x}$ & $\mathrm{x}$ & & $\mathrm{x}$ \\
\hline $\begin{array}{l}\text { Economic } \\
\text { sector damage }\end{array}$ & $\mathrm{x}$ & $\mathrm{x}$ & & $\mathrm{x}$ \\
\hline Geophysical & $\mathrm{x}$ & $\mathrm{x}$ & $\mathrm{x}$ & $\mathrm{x}$ \\
\hline Hydrological & $\mathrm{x}$ & $\mathrm{x}$ & $\mathrm{x}$ & $\mathrm{x}$ \\
\hline Meteorological & $\mathrm{x}$ & $\mathrm{x}$ & $\mathrm{x}$ & $\mathrm{x}$ \\
\hline Climatological & $\mathrm{x}$ & $\mathrm{x}$ & $\mathrm{x}$ & $\mathrm{x}$ \\
\hline Biological & $\mathrm{x}$ & & $\mathrm{x}$ & $\mathrm{x}$ \\
\hline Technological & $\mathrm{x}$ & & $\mathrm{x}$ & $\mathrm{x}$ \\
\hline Climate change & & & & \\
\hline
\end{tabular}

Source: Adapted from IRDR (2014)

Another publicly accessible, global database is the global disaster identifier number (GLIDE) database. This database is collaboration between CRED, ISDR, UNDP, La Red/DesInventar, and others. The mission of this database is not the rigorous documentation of loss information but linking disaster loss databases through the establishment of a disaster event identifier (Tschoegl, 2006). The Asian Disaster Reduction Center (ADRC), which maintains the GLIDE database, generates a unique identifier for each disaster event to link loss information and to advance event and data comparability between databases. Similar to EM-DAT, GLIDE also imposes an event threshold hereby excluding high frequency-low impact events. GLIDE contains about 5,000 records (IRDR, 2014). In addition to these publicly accessible, global disaster loss databases, there are many databases of proprietary nature - particularly in the insurance 
and re-insurance sectors, which are outlined in Table 1 and discussed elsewhere (Smolka, 2006; UNDP/BCPR, 2013; Kron et al., 2012).

Generally speaking, EM-DAT and GLIDE serve the international (humanitarian aid) and research community. National databases, on the other hand, tend to provide a richer data set that informs national and sub-national planners, stakeholders, decision-makers, emergency managers, and others as exemplified by the extensive use of the national disaster loss databases for hazard mitigation planning in the USA (FEMA, 1997, HVRI, 2013). As a result, the number of national, publicly accessible databases has significantly increased over the past decade reflecting the need and relevance of tracking disaster impacts at the local level. At present, there are 42 disaster loss databases at the national or regional level (Table 2).

Table 2 Alphabetical list of national and regional disaster loss databases

\begin{tabular}{|c|c|c|c|}
\hline Country & Type & Ownership & $\begin{array}{l}\text { Temporal } \\
\text { coverage }\end{array}$ \\
\hline $\begin{array}{l}\text { Andean } \\
\text { Information } \\
\text { System for Disaster } \\
\text { Prevention and } \\
\text { Relief }\end{array}$ & Regional & $\begin{array}{l}\text { Andean Information System for Disaster } \\
\text { Prevention and Relief }\end{array}$ & N/A \\
\hline Argentina & DesInventar & Centro Estudios Sociales y Ambientales & 1970-2009 \\
\hline Australia & National & Emergency Management Australia & 1622-present \\
\hline Bangladesh & National & $\begin{array}{l}\text { Ministry of Food and Disaster } \\
\text { Management }\end{array}$ & 1970-2009 \\
\hline Barbados & $\begin{array}{l}\text { Regional, } \\
\text { DesInventar }\end{array}$ & $\begin{array}{c}\text { Caribbean Disaseter Emergency Response } \\
\text { Agency }\end{array}$ & N/A \\
\hline Bolivia & DesInventar & Viceministerio de Defensa Civil & $1970-2010$ \\
\hline Canada & National & Public Safety & 1900-present \\
\hline Chile & DesInventar & $\begin{array}{c}\text { Department of Environmental Sciences } \\
\text { and Natural Resources of the University of } \\
\text { Chile }\end{array}$ & 1970-2009 \\
\hline Colombia & DesInventar & OSSO Corporation & 1914-2011 \\
\hline Costa Rica & DesInventar & $\begin{array}{l}\text { Comisión Nacional de Prevención de } \\
\text { Riesgo y Atención de Emergencias }\end{array}$ & $1970-2010$ \\
\hline $\begin{array}{l}\text { Dominican } \\
\text { Republic }\end{array}$ & DesInventar & LaRed & 1970-2009 \\
\hline Ecuador & DesInventar & Secretaría Nacional de Gestion de Riesgo & $1970-2010$ \\
\hline Egypt & DesInventar & Information and Decision Support Center & 1980-2010 \\
\hline El Salvador & DesInventar & National Service of Territorial Studies & 1900-2011 \\
\hline Guatemala & DesInventar & Facultad Latinoamericana de Ciencias & 1988-2010 \\
\hline Guyana & DesInventar & Sociales & 1972-2011 \\
\hline Honduras & DesInventar & $\begin{array}{l}\text { Permanent Commission for Emergency } \\
\text { Management }\end{array}$ & 1998-1999 \\
\hline India & $\begin{array}{l}\text { Regional, } \\
\text { DesInventar }\end{array}$ & $\begin{array}{c}\text { State Disaster Management Authority of } \\
\text { Mizoram }\end{array}$ & $1992-2010$ \\
\hline
\end{tabular}


Table 2 Alphabetical list of national and regional disaster loss databases (continued)

\begin{tabular}{|c|c|c|c|}
\hline Country & Type & Ownership & $\begin{array}{l}\text { Temporal } \\
\text { coverage }\end{array}$ \\
\hline Indonesia & DesInventar & $\begin{array}{l}\text { National Agency for Disaster Management } \\
\text { (BNPB) }\end{array}$ & 1815-present \\
\hline Iran & DesInventar & UNDP & $1895-2011$ \\
\hline Jamaica & DesInventar & University of West Indies & 1973-2002 \\
\hline Jordan & DesInventar & Civil Defense & $1981-2010$ \\
\hline Laos & DesInventar & National Disaster Management Office & 1990-2012 \\
\hline Maledives & DesInventar & Ministry of Defense & $1980-2007$ \\
\hline Mali & DesInventar & Protection Civile & 1999-2012 \\
\hline Mexico & DesInventar & La Red & 1970-2009 \\
\hline Morocco & DesInventar & Ministry of Environment & 1970-2009 \\
\hline Mozambique & DesInventar & National Disaster Management Institute & 1979-2009 \\
\hline Nepal & DesInventar & $\begin{array}{c}\text { National Society for Earthquake } \\
\text { Technology }\end{array}$ & 1971-present \\
\hline Nicaragua & DesInventar & Ministry of Defense & 1998-1999 \\
\hline Panama & DesInventar & Sistema Nacional de Protección Civil & 1929-2011 \\
\hline Peru & DesInventar & $\begin{array}{c}\text { Centro de Estudios y Prevencion de } \\
\text { Desastres }\end{array}$ & 1970-1999 \\
\hline Philippines & $\begin{array}{l}\text { National } \\
\text { (password } \\
\text { required) }\end{array}$ & $\begin{array}{c}\text { Office of Civil Defense, National Disaster } \\
\text { Coordinating Council }\end{array}$ & 1969-2009 \\
\hline Solomon Islands & DesInventar & SOPAC & $1568-1964$ \\
\hline Sri Lanka & DesInventar & Disaster Management Center & 1974-present \\
\hline Timor Leste & DesInventar & National Disaster Management Directorate & $2001-2011$ \\
\hline Trinidad - Tobago & DesInventar & $\mathrm{n} / \mathrm{a}$ & N/A \\
\hline USA & National & $\begin{array}{l}\text { Hazards Vulnerability and Research } \\
\text { Institute, University of South Carolina }\end{array}$ & 1960-present \\
\hline USA & National & National Climatic Data Center & 2006-present \\
\hline Venezuela & DesInventar & CENAPRED & 1970-2007 \\
\hline Vietnam & National & $\begin{array}{l}\text { Central Committee for Flood and Storm } \\
\text { Control }\end{array}$ & 1989-2008 \\
\hline Yemen & DesInventar & Ministry of Environment & 1970-2011 \\
\hline
\end{tabular}

For the purpose of this paper, only active, and regularly updated, national databases covering climate-sensitive hazards were included in Table 2. The overview of databases presented here draws on the disaster loss database catalogue hosted by the Global risk information platform (GRIP). Figure 1 provides a map of active, national disaster loss databases. International databases such as EM-DAT and GLIDE were excluded from this discussion due to their application of event thresholds, which makes it nearly impossible for slow onset and/or low-impact event to make it into the database. 
Figure 1 Countries shaded in grey are covered by one or more national/regional disaster loss databases (see online version for colours)

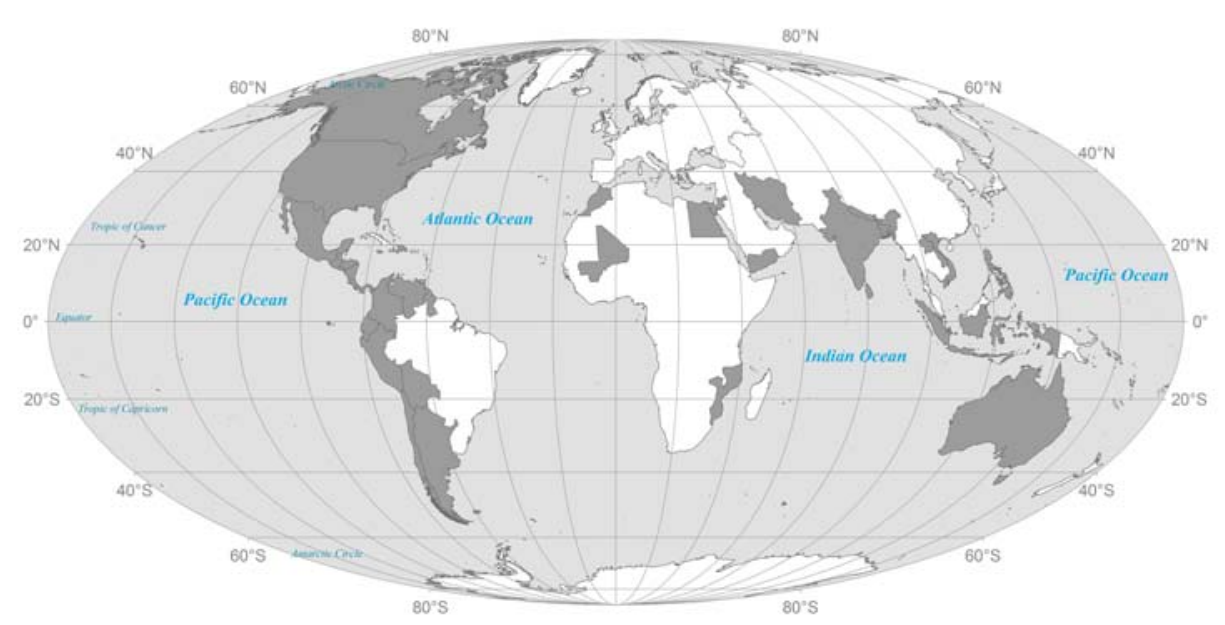

\subsection{Attributes and metrics of disaster loss databases}

Every database utilises its own suite of hazards, loss metrics (e.g., fatalities, displaced populations, etc.), spatial resolution (e.g., neighbourhood, city, province, etc.), and covers different time periods (Table 1). However, many databases share the same underlying data management structure. Currently, about three quarters of national databases utilise the DesInventar data management approach (Table 2). This data management system consists of guidelines for data collection, data entry and database management along with a database and data entry interface (DesInventar, 2009; UNDP, 2009). At present, 33 out of the 42 disaster loss databases are utilising the DesInventar system. The DesInventar system will therefore serve as an example of a disaster loss database and its suitability for climate impact assessments. References to other national databases are made where applicable to illustrate advantages or shortcomings of the DesInventar approach.

Dating back to the mid-1990s, members of the Network of Social Studies in the Prevention of Disasters in Latin America (LA RED) initiated the systematic data collection of loss information in Latin America. The group's brainchild was the development of the tools and methodology behind the Disaster Inventory System, better known as DesInventar. DesInventar includes a wide range of hazards including meteorological, hydrological, geological, biological, technological and chemical events (Table 2) (DesInventar, 2009). In regard to climate-sensitive hazards, DesInventar covers both extreme weather events as well as some slow onset events, i.e., avalanche, biodiversity decline, biological hazards (e.g., influenza outbreak, locusts), coastline changes, drought, fog, frost, hail, heavy rainfall, heavy snowfall, high winds, lightning, mass movements (e.g., landslides, mudslides, etc.), riverine and flash floods, sedimentation and accretion, severe thunderstorm, storm surge, tornado, tropical cyclones, and wildfires. DesInventar does not explicitly include sea-level rise although its impact maybe inferred from hazards such as coastline changes, sedimentation and accretion, storm surge, and flooding. 
The quantification of losses in DesInventar relies on secondary data sources (e.g., newspapers, NGO reports, government reports, etc.). There are no event thresholds meaning all events, large and small, are entered into the database as long as they trigger a loss. Loss metrics are captured at various scales and can range from sub-national levels to city neighbourhoods depending on data availability. A record in the DesInventar database includes a time stamps (event start and end date), location of event/impact, type of hazard, along with various loss categories (Table 2). For more technical information see DesInventar (2009).

What is and is not included in disaster loss databases dates back to the decisions made during the design process and the purpose of the database (Gall et al., 2009). Some databases resort to the smallest common denominator in loss estimates and report only hazard type, location, date, fatalities, injuries and monetised direct losses (see SHELDUS ${ }^{\circledR}$ database in the US). Using a small set of variables has the advantage that all events in the database are likely to have complete information across all variables. DesInventar databases, on the other hand, have about 15 different loss categories (DesInventar, 2009). Although, a broad set of loss metrics appear to capture impacts comprehensively, such detailed information is frequently not available limiting comparability between events due to missing data (UNDP/BCPR, 2013). Not only is it difficult to obtain reliable information on all these attributes but there is a high probability of overlapping information and double-counting.

\subsection{Not all extreme weather events are created equal in a disaster loss database}

Disaster loss databases such as DesInventar or EM-DAT are imperfect. Gall et al. (2009) identified several shortcomings of disaster loss databases. Common weaknesses of disaster loss databases are the over- or under-reporting of certain hazard types (hazard bias), gaps in historic records (temporal bias), reliance on direct and/or monetised losses (accounting bias), focus on high impact and/or acute events (threshold bias), and over-representation of densely population and/or easily accessible areas (geography bias).

How these biases are introduced into disaster loss databases? Most stem from data availability issues. First, many countries have a short or spotty climatological record of extreme weather events making it difficult to identify extreme events, not to mention their impacts. The result is a temporal bias towards recent history in most national disaster loss databases. A short loss record makes it challenging to establish a baseline for disaster losses, which in return limits the possibility to identify trends in risk management and resilience, and increases the likelihood that recent disaster losses are confounded by climate change effects.

Second, data availability or unavailability is not uniform across all hazard types leading to a preferential reporting of certain hazard types (hazard bias). In the USA, for example, the National Weather Service is tasked by the US Army Corps of Engineers to furnish loss estimates on every flood event (NWS, 2009). At the same time, the National Weather Service significantly underreports drought events, which are captured by the US Department of Agriculture but not integrated into national disaster loss databases (Smith and Katz, 2013). This obviously leads to a strong imbalance in loss reporting - and potentially risk management - between floods and droughts in the US.

Third, losses are generally estimates derived from secondary, public sources such as newspapers, public officials, and so forth, which are often unverified and unvetted (Gall 
et al., 2009; NWS, 2009). This creates competing estimates of unknown quality and origin (Guha-Sapir and Below, 2006). As a result, loss estimates for the same event tend to vary dramatically between loss databases (Guha-Sapir and Below, 2002, 2006). For example, estimates of losses from the 2011 Japan earthquake range from over US\$ 170 billion and 14,000 fatalities (Norio et al., 2011) to around US\$ 309 billion and 16,000 fatalities (USGS, 2013).

The reason for such discrepancies lays either in the inclusion/exclusion of different impact types (e.g. insured losses, indirect, etc.) and/or in crude estimation techniques. Smith and Katz (2013) found that national-level loss databases in the US significantly underreport disaster losses due to their reliance on public sources and exclusion (or inaccessibility) of loss information from commercial as well as federal institutions that collect insured losses.

And lastly, the reliance on direct loss measures such as fatalities and property damage (accounting bias) hinges squarely on the unavailability of indirect loss estimates across the entire spectrum of event magnitudes (small to large scale), frequency (high to low), and types (i.e., all natural hazards). Providing indirect loss estimates in an operational setting requires modelling capabilities and resources, which are usually not available in local meteorological offices, the main provider of loss information in most countries. Indirect loss estimates are of particular importance to slow onset events and are therefore discussed in more detail in Section 4.2 of this paper.

As illustrated, data (un-)availability regarding the occurrence of extreme weather events as well as loss estimates of questionable quality are major factors in the quality and representativeness of disaster loss databases (Bouwer et al., 2007). These shortcomings though are frequently undetectable to data users since their identification requires a sound understanding of underlying database structure, database mission, data availability, quality of data sources, and more. Being aware of one or more of these biases is essential for a sound interpretation of trends and patterns in disaster risk management and climate change adaptation.

In sum, disaster loss databases represent the best available data to monitor loss and damage from climate change without necessarily offering data of the highest quality. There is significant room for improving the qualitative, spatial, and temporal coverage as well as the quantitative accuracy of loss information. This can be achieved, first and foremost, by improving data availability and the capacity to monitor extreme weather events as well as producing sound loss estimates - capabilities that many countries in both the developed and developing world possess only marginally(UNDP/BCPR, 2013).

\section{Measuring the impacts from slow onset events}

\subsection{Where are slow onset events in disaster loss databases?}

Hazards are generally classified based on origin (e.g., geological, hydrological, meteorological, technological, biological or man-made) or characteristics (e.g., magnitude, speed of onset, duration, etc.). Existing disaster loss databases utilise the origin-based hazard classification approach (IRDR, 2014). For example, a flood event falls into the category of hydrological hazards, which is then further broken down by flood type (e.g., riverine flood, flash flood, ice jam flooding, levee failure, storm surge, etc.). 
Most disaster loss databases contain only few slow onset hazards, and in many cases it is limited to droughts alone. DesInventar databases consider a small number slow onset hazard, which includes drought, coastline changes and biodiversity decline. To capture and document the adverse effects of slow onset events brought on by climate change, 'new' hazard types, in the sense of being new additions to disaster loss databases, need to be developed. Ideally, these 'new' hazard types follow the origin-based logic - perhaps even establish new hazard origins (e.g., ocean acidification, sea-level rise, etc.) - to stay consistent with existing approaches. But as O'Brien et al. (2006, p.68) put it, "climate change is a multi-faceted (from drought to flood) and multidimensional (from local to global) hazard that has short-, medium-, and long-term aspects and unknown outcomes" and therefore does not fit smoothly in either the origin- or characteristics-based hazard classification system.

When developing 'new' slow onset hazard types for use in disaster loss databases, it is imperative that these hazard types possess enough specificity to establish a causal relationship between the hazard and its impacts. This will require translating slow onset events such as ocean acidification, sea-level rise, and others into more specific, damage-causing hazard types. For instance, sea-level rise itself does not cause damage but hazards such as coastal erosion, saltwater intrusion, coastal flooding, etc. do. Hence, 'new' sets of slow onset hazard types should be integrated in disaster loss databases to start capturing impacts from climate change beyond extreme weather events.

\subsection{The forgotten impacts of slow onset events}

Slow onset events tend to cause limited direct impacts. Instead they trigger large ripple effects with significant indirect losses and macro-economic effects (Pelling et al., 2002). Unfortunately, disaster loss databases rarely include indirect and non-economic losses, and if so it is at a very generic level. For example, DesInventar offers absolute counts of indirectly affected facilities without providing dollar estimates. Thefocus on direct loss estimates is representative across all disaster loss databases and not unique to the DesInventar database.

Estimating indirect and non-monetised losses for every loss event at an operational level is not only difficult methodically but relies on a systems-approach that varies by assessment scale and purpose further complicating the estimation of indirect and non-monetised losses. Although, there are sophisticated methods for calculating indirect losses, this information is generally only available for specific case studies and/or large-scale disasters (Brookshire et al., 1997; Hallegatte, 2008). Economic techniques for modelling indirect losses exist (e.g., lost productivity, ecosystem valuation, econometric models, general equilibrium models, ECLAC methodology, etc.) (Cochrane, 2004; Constanza, 2012; Cropper and Sahin, 2009; Pelling et al., 2002) but are not used operationally in disaster loss databases. As a result, the documentation of indirect losses in loss databases is rudimentary - often a mere multiplication of direct or insured losses using subjective multiplication factors (Barthel and Neumayer, 2012; Smith and Katz, 2013).

There is a huge potential to advance loss estimation techniques by including impacts on informal economies, adverse environmental effects and perhaps attempting to value (monetise) those effects. Drawing on techniques in cost-benefit analysis (Michel-Kerjan et al., 2012; Burbank, 2009), ecosystem valuation research (Daniel et al., 2012), or the methodology developed by the European Commission for Latin America and the 
Caribbean (ECLAC) (Below et al., 2007; Pelling et al., 2002) could possibly provide a starting point for advancing indirect loss assessments. If valuation cannot be achieved in the near future, an alternative solution could be an increased use of multiplication factors, or establishing more qualitative loss categories, i.e., the use of absolute counts or descriptions as implemented in DesInventar databases (e.g., abandonment of heritage sites, abandonment of territory, etc.), although such an approach would introduce a significant amount of uncertainty.

In their current form, disaster loss databases are hardly equipped to measure loss and damage from slow onset events because they:

a do not consider the broad spectrum of climate-induced, slow onset hazard types

b have no readily available methodology at their disposal that would allow rapid estimation of indirect losses.

As mentioned previously though, disaster loss databases consolidate loss information from various sources and do not generate loss estimates themselves. Estimating indirect losses goes beyond the mission and scope of operators of disaster loss database and requires resolution and commitments elsewhere (e.g., local weather offices, national census bureaus, etc.).

\subsection{The 'incubation' time of slow onset event}

Possibly the most critical concern regarding the suitability of disaster loss database for capturing the impact of slow onset events is the limited time frame that is generally applied to the determination of impacts. Direct losses occur during the actual exposure to the event. Indirect and non-monetised losses as well as adaptation costs/investments accrue gradually over time. For example, saltwater intrusion due to sea-level rise affects not only planted crops but also future harvests. Thus, the loss occurs not only once but persists over many months, years, decades, etc. In fact, for how long should indirect losses be assessed? If there is no end date, will indirect loss estimates from climate change require perpetual adjustments?

This time lag in the manifestation of losses from slow onset events necessitates ongoing reviews and updates of loss estimates over the course of weeks, months or perhaps even years after the event. To capture such delayed impacts in disaster loss databases, revised estimates must be made available on a regular basis to database operators - a problem that will be difficult to address considering already existing challenges and resource constraints surrounding data availability for extreme weather events discussed earlier.

\section{Additional suggestions on how to better utilise disaster loss databases for loss and damage assessments}

Taking a fresh look at the benefits and shortcoming of existing disaster loss databases and exploring their potential for documenting loss and damage associated with climate change provides an opportunity to: 
b advance loss estimation both for disaster risk management as well as climate adaptation.

To advance the reliability and accuracy of disaster loss databases, it is necessary to:

1 improve data availability in regard to the climatological record of extreme weather events

2 place equal importance on all hazard types and represent their impacts equitable in the database

3 improve the quality and accuracy of direct and indirect loss estimates

4 compile loss estimates from largely untapped sources such as the insurance industry, governmental agencies, and others

5 develop 'new' climate-related hazard types for slow onset events

6 incorporate indirect and non-monetised loss estimates, even at a very basic level

7 expand the time horizon during which indirect losses are assessed.

Based on lessons learned in the disaster risk community (Di Mauro et al., 2013; Wirtz et al., 2014), some additional recommendations should be implemented to increase the usefulness of disaster loss databases.

\subsection{Develop loss and damage procedures and standards}

Aside from the above listed recommendations, there is an ongoing need for the establishment of technical standards for disaster loss databases to ensure database comparability and compatibility (Wirtz et al., 2014; UNDP, 2009; UNDP/BCPR, 2013; IRDR, 2014). At present, disaster loss databases are tailored to national needs without any concern for database compatibility. This hampers the ability to aggregate and consolidate losses across time, space, hazards, and loss metrics - a critical need of the climate change community where both an understanding of local as well as regional and global conditions are essential for the development of adaptation strategies. For example, DesInventar databases do not use the term landslide - generally defined as the movement of wet and/or dry materials down a slope (Keller et al., 2012). Instead, DesInventar uses the term 'alluvium' - defined as torrents of water, which drag great quantities of solid material (pebbles, graceland rocks) (DesInventar, 2009). How to aggregate landslide losses from different databases when terminology and definitions are not standardised? This is not a trivial issue and poses a major obstacle in utilising data from different databases as evidenced by the efforts of the integrated research on disaster risk (IRDR). The IRDR working group on loss data brings together national and international database operators to foster collaboration and harmonise operational procedures. The recently released peril classification and hazard terminology by this working group (IRDR, 2014) is a first step towards a common standard for disaster loss databases.

However, this standardisation effort is steeped in disaster risk management traditions and does not (yet) consider categories for hazards arising from climate change (e.g., coral bleaching, desertification, etc.). Initiating a joined loss standardisation/harmonisation effort between the disaster risk and climate change community would provide an 
opportunity to expand traditional loss assessments and to develop new methods for indirect and non-monetised losses that would benefit both communities.

\subsection{Document the costs and investments related to climate change adaptation}

Risk reducing decision-making requires an understanding of incurred losses, as documented in disaster loss databases, but also a better understanding of the effectiveness of adaptation investments. To evaluate risk management strategies, both pieces of information, i.e., investments and losses, are necessary. Although, adaptation investments occur at various levels ranging from households and businesses to local communities up to the highest levels of government, for practicality purposes, it is recommended to focus on public investments in climate adaptation and utilise the same unit of analysis at which disaster losses are collected.

There are climate adaptation libraries (e.g., adaptation database for planning tool/ADAPT, Climate adaptation knowledge exchange/CAKE, climate adaptation case studies/CASES, etc.), which offer case study reports, visualisation tools, and other valuable qualitative information - but there are few databases tracking costs and investments of disaster risk reduction at governmental levels (e.g., PERI Presidential Disaster Declaration Database) and there are none on climate adaptation. Only few case studies exist that trace the relationship between adaptation investments and avoided losses from disasters (Tol, 2003; Multihazard Mitigation Council, 2005). Better data on effective adaptation strategies could aid in establishing risk transfer mechanism as requested by many developing countries in the UNFCCC negotiation process and garner support for future investments while enhancing accountability and transparency.

\section{Conclusions}

Overall, disaster loss database have potential for assessing the impact from climate change, though, they require modifications to enhance their utility. Among the nine recommendations outlined above, the issues of data availability as well as quality (Bouwer et al., 2007) along with new loss metrics, primarily indirect measures, emerge as critical components. To address these issues and implement solutions, concerted efforts and capacity building efforts at the regional and national levels will be of crucial importance.

Furthermore, the driving forces of losses call for more attention. Loss estimates provide crucial - although incomplete - data for exploring the relationship between climate change and its effects on climate-sensitive hazards as well as loss and damage. Presently, the IPCC sees no evidence for a climate change signal in globally rising losses (IPCC, 2012). In order to attribute losses to climate change, physical parameters of climate change (e.g., carbon dioxide concentration, air temperature, sea-level rise, etc.) as well as data on loss and damage have to be collected (Huggel et al., 2013; Bouwer, 2011). The ability to establish a cause-and-effect relationship between climate change and losses depends on the availability and accuracy of information on loss and damage, climate and weather patterns, as well as socioeconomic and ecological conditions. While climate change alters the hazard, societal changes such as urbanisation alter resilience. Establishing a link between disaster impacts and climate change requires better knowledge on all fronts: climatology, impacts, and resilience. 
Since the conference of parties (COP19) in Warsaw, Poland, in 2013, a new pathway exists through which some of these recommendations can be implemented - the Warsaw International Mechanism for Loss and Damage associated with Climate Change Impacts (the so-called L\&D Mechanism). The purpose of the L\&D Mechanism is to:

a advance the understanding of comprehensive risk management strategies

b foster stakeholder coordination, dialogue and synergies

c support financial, technical, and capacity-building efforts to implement and develop approaches that reduce loss and damage from extreme weather events and slow onset events (UNFCCC, 2013).

Data contained in existing disaster loss databases can support the activities of L\&D Mechanism, while in return the L\&D Mechanism could advocate for improvements to disaster loss databases to overcome the shortcomings discussed in this paper.

\section{Acknowledgements}

I am grateful for the comments by three anonymous reviewers, which improved the manuscript, and I take full responsibility for any remaining shortcomings. This paper draws on the report Measuring What Matters? A Suitability Analysis of Loss and Damage Databases for the Climate Change Convention Process co-authored with Sönke Kreft for the Climate \& Development Knowledge Network (CDKN). This report along with other loss and damage related publications can be downloaded at http://www.lossand damage.net.

\section{References}

Adger, W.N. (2006) 'Vulnerability', Global Environmental Change, Vol. 16, No. 3, pp.268-281, doi:10.1016/j.gloenvcha.2006.02.006.

Adger, W.N., Dessai, S., Goulden, M., Hulme, M., Lorenzoni, I., Nelson, D.R., Naess, L.O., Wolf, J. and Wreford, A. (2008) 'Are there social limits to adaptation to climate change?', Climatic Change, Vol. 93, Nos. 3-4, pp.335-354, doi:10.1007/s10584-008-9520-z.

Barthel, F. and Neumayer, E. (2012) 'A trend analysis of normalized insured damage from natural disasters', Climatic Change, Vol. 113, No. 2, pp.215-237, doi:10.1007/s10584-011-0331-2.

Below, R., Grover-Kopec, E. and Dilley, M. (2007) 'Documenting drought-related disasters: a global reassessment', The Journal of Environment \& Development, Vol. 16, No. 3, pp.328-344, doi:10.1177/1070496507306222.

Below, R., Wirtz, A. and Re, M. (2009) Working Paper Disaster Category Classification and Peril Terminology for Operational Purposes [online] http://www.cred.be/publication/disastercategory-classification-and-peril-terminology-operational-purposes (accessed 2 September 2014).

Bouwer, L.M. (2011) 'Have disaster losses increased due to anthropogenic climate change?', Bulletin of the American Meteorological Society, Vol. 92, No. 1, pp.39-46, doi:10.1175/ 2010BAMS3092.1.

Bouwer, L.M., Crompton, R.P., Faust, E. and Höppe, P. (2007) 'Confronting disaster losses', Science, Vol. 318, No. 5851, p.753. 
Brookshire, D.S., Chang, S.E., Cochrane, H., Olson, R.A., Rose, A. and Steenson, J. (1997) 'Direct and indirect economic losses from earthquake damage', Earthquake Spectra, Vol. 13, No. 4, pp.683-701.

Burbank, K. (2009) 'An economist's role in disaster mitigation at FEMA', Business Economics, Vol. 44, No. 3, pp.177-181, doi:10.1057/be.2009.17.

Cochrane, H. (2004) 'Economic loss: myth and measurement', Disaster Prevention and Management, Vol. 13, No. 4, pp.290-296.

Constanza, R. (2012) 'The value of natural and social capital in our current full world and in a sustainable and desirable future', in Weinstein, M.P. and Turner, R.E. (Eds.): Sustainability Science: The Emerging Paradigm and the Urban Environment, pp.99-109, Springer, New York.

CRED (2012) EM-DAT: The International Disaster Database, Leuven University, Brussels [online] http://www.emdat.be (accessed 2 September 2014).

Cropper, M.L. and Sahin, S. (2009) Valuing Mortality and Morbidity in the Context of Disaster Risks, The World Bank, Washington, DC.

Cutter, S.L., Burton, C.G. and Emrich, C.T. (2010) 'Disaster resilience indicators for benchmarking baseline conditions', Journal of Homeland Security and Emergency Management, Vol. 7, No. 1, Article 51, doi:51.

Daniel, T.C., Muhar, A., Arnberger, A., Aznar, O., Boyd, J.W., Chan, K.M. and Costanza, R. et al. (2012) 'Contributions of cultural services to the ecosystem services agenda', Proceedings of the National Academy of Sciences of the United States of America, Vol. 109, No. 23, pp.8812-8819, doi:10.1073/pnas.1114773109.

DesInventar (2009) Disaster Inventory System: Methodological Guide, Version 8.1.9 [online]

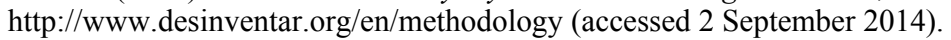

Di Mauro, M., McLean, L., Guha-Sapir, D., Wirtz, A., Eichner, J. and Dilley, M. (2013) Risk Information Issues and Needs: An Overview, Geneva, Switzerland [online] http://www.wmo.int/pages/prog/drr/projects/Thematic/HazardRisk/2013-10-TC-Prog-FPMeeting/documents/Doc\% $\% 20620$

\%20Risk\%20information\%20issues\%20and\%20needs\%20synthesis\%20paper.pdf (accessed Sept 2, 2014).

Dow, K., Berkhout, F., Preston, B.L., Klein, R.J.T., Midgley, G. and Shaw, M.R. (2013) 'Limits to adaptation', Nature, Vol. 3, pp.305-307.

Emanuel, K.A. (2005) 'Increasing destructiveness of tropical cyclones over the past 30 years', Nature, Vol. 436, No. 7051, pp.686-688.

FEMA (1997) Multihazard Identification and Risk Assessment: A Cornerstone of the National Mitigation Strategy, Federal Emergency Management Agency (FEMA), Washington DC.

Gall, M., Borden, K.A. and Cutter, S.L. (2009) 'When do losses count?', Bulletin of the American Meteorological Society, Vol. 90, No. 6, pp.799-809, doi:10.1175/2008BAMS2721.1.

Gall, M., Borden, K.A., Emrich, C.T. and Cutter, S.L. (2011) 'The unsustainable trend of natural hazard losses in the United States', Sustainability, Vol. 3, No. 11, pp.2157-2181.

Glavovic, B.C. and Smith, G.P. (Eds.) (2014) Adapting to Climate Change: Lessons from Natural Hazards Planning, Springer, Dordrecht, The Netherlands.

GRIP. Disaster Databases [online] http://www.gripweb.org/gripweb/?q=disaster-database (accessed 2September 2014).

Guha-Sapir, D. and Below, R. (2002) The Quality and Accuracy of Disaster Data: A Comparative Analysis of Three Global Data Sets. The World Bank, Geneva [online] http://www.cred.be/publication/quality-and-accuracy-disaster-data-comparative-analyse-3global-data-sets (accessed 2 September 2014).

Guha-Sapir, D. and Below, R. (2006) 'Collecting data on disasters: easier said than done', Asian Disaster Management News, Vol. 12, No. 2, pp.9-10.

Hall, J.W., Brown, S., Nicholls, R.J., Pidgeon, N.F. and Watson, R.T. (2012) 'Proportionate adaptation', Nature Climate Change, Vol. 2, No. 12, pp.833-834, doi:10.1038/nclimate1749. 
Hallegatte, S. (2008) 'An adaptive regional input-output model and its application to the assessment of the economic cost of Katrina', Risk Analysis, Vol. 28, No. 3, pp.779-799, doi:10.1111/j.1539-6924.2008.01046.x.

Hazards \& Vulnerability Research Institute (HVRI) (2013) The Spatial Hazard Events and Losses Database for the United States, Version 12.0 [Online Database], University of South Carolina, Columbia, SC [online] http://www.sheldus.org (accessed 31 March 2013).

Huggel, C., Stone, D., Auffhammer, M. and Hansen, G. (2013) 'Loss and damage attribution', Nature Publishing Group, Vol. 3, No. 8, pp.694-696, doi:10.1038/nclimate1961.

IPCC (2012) Managing the Risks of Extreme Events and Disasters to Advance Climate Change Adaptation, Field, C.B., Barros, V., Stocker, T.F. and Dahe, Q. (Eds.), Cambridge University Press, Cambridge, doi:10.1017/CBO9781139177245.

IRDR (2014) Peril Classificationa and Hazard Terminology, Beijing, China [online] http://www.irdrinternational.org/irdr-publications/ (accessed 2 September 2014).

Jagger, T.H., Elsner, J.B. and Burch, R.K. (2011) 'Climate and solar signals in property damage losses from hurricanes affecting the United States', Natural Hazards, Vol. 58, No. 1, pp.541-557, doi:10.1007/s11069-010-9685-4.

Janssen, M.A. and Ostrom, E. (2006) 'Resilience, vulnerability and adaptation: a cross-cutting theme of the international human dimensions programme on global environmental change', (editotrial), Global Environmental Change, Vol. 16, No. 3, pp.237-239, doi:10.1016/ j.gloenvcha.2006.04.003.

Kates, R.W., Travis, W.R. and Wilbanks, T.J. (2012) 'Transformational adaptation when incremental adaptations to climate change are insufficient', Proceedings of the National Academy of Sciences of the United States of America, Vol. 109, No. 19, pp.7156-7161, doi:10.1073/pnas.1115521109.

Keller, E.A., DeVecchio, D.E. and Blodgett, R.H. (2012) Natural Hazards: Earth's Processes as Hazards, Disasters and Catastrophes, 3rd eds., Prentice Hall, Uppder Saddle River, New Jersey.

Klinke, A. and Renn, O. (2002) 'A new approach to risk evaluation and management: risk-based, precaution-based, and discourse-based strategies 1', Risk Analysis, Vol. 22, No. 6, pp.1071-1094, doi:10.1111/1539-6924.00274.

Kron, W., Steuer, M., Löw, P. and Wirtz, A. (2012) 'How to deal properly with a natural catastrophe database - analysis of flood losses', Natural Hazards and Earth System Science, Vol. 12, No. 3, pp.535-550, doi:10.5194/nhess-12-535-2012.

Michel-Kerjan, E.O., Hochrainer-Stigler, S., Kunreuther, H.C., Linnerooth-Bayer, J., Mechler, R., Muir-Wood, R., Ranger, N., Vaziri, P. and Young, M. (2012) 'Catastrophe risk models for evaluating disaster risk reduction investments in developing countries', Risk Analysis, Vol. 33, No. 6, pp.984-999.

Miller, F., Osbahr, H., Boyd, E., Thomalla, F., Bharwani, S., Ziervogel, G., Walker, B. et al. (2010) 'Resilience and vulnerability: complementary or conflicting concepts?', Ecology and Society, Vol. 15, No. 3, p.11.

Morgan, J. and Waskow, D. (2013) 'A new look at climate equity in the UNFCCC', Climate Policy, Vol. 14, No. 1, pp.17-22, Taylor Publisher, doi:10.1080/14693062.2014.848096.

Moser, S.C. and Ekstrom, J.A. (2010) 'A framework to diagnose barriers to climate change adaptation', Proceedings of the National Academy of Sciences of the United States of America, Vol. 107, No. 51, pp.22026-31, doi:10.1073/pnas.1007887107.

Multihazard Mitigation Council (2005) Natural Hazard Mitigation Saves: An Independent Study to Assess the Future Savings from Mitigation Activities, National Institute of Buildings Sciences, Washington, DC [online] http://www.nibs.org/MMC/mmcactiv5.html http://www.floods.org/PDF/MMC_Volume1_FindingsConclusionsRecommendations.pdf (accessed 2 September 2014). 
Munich RE (2009) Climate Change, Climate Risk, Climate Chance, Münchener Rückversicherungs-Gesellschaft, Munich, Germany [online] http://www.munichre.com/ app_pages/corporate-responsibility/@res/pdf/302-05874_en.pdf (accessed 31 March 2013).

Nicholls, R.J., Hoozemans, F.M.J. and Marchand, M. (1999) 'Increasing flood risk and wetland losses due to global sea-level rise: regional and global analyses', Global Environmental Change, Vol. 9, Supplement 1, pp.S69-S87, doi: Doi: 10.1016/s0959-3780(99)00019-9.

Norio, O., Ye, T., Kajitani, Y., Shi, P. and Tatano, H. (2011) 'The 2011 Eastern Japan great earthquake disaster: overview and comments', International Journal of Disaster Risk Science, Vol. 2, No. 1, pp.34-42.

NRC (1999) The Impacts of Natural Disasters: A Framework for Loss Estimation, The National Academies Press, Washington, DC.

NWS (2009) Storm Data Preparation, Department of Commerce, National Oceanic \& Atmospheric Administration, National Weather Service (NWS), Silver Spring, MD [online] http://www.nws.noaa.gov/directives/ (accessed 2 September 2014).

O'Brien, G., O'Keefe, P., Rose, J. and Wisner, B. (2006) 'Climate change and disaster management', Disasters, Vol. 30, No. 1, pp.64-80.

Oliver-Smith, A., Cutter, S.L., Warner, K., Cosmin, C. and Yuzva, K. (2012) Addressing Loss and Damage in the Context of Social Vulnerability and Resilience, United Nations University Institute for Environment and Human Security (UNU-EHS), Bonn, Germany.

Pelling, M., Özerdem, A. and Barakat, S. (2002) 'The macro-economic impact of disasters', Progress in Development Studies, Vol. 2, No. 4, pp.283-305, doi:10.1191/1464993402 ps042ra.

Pielke Jr., R.A., Sarewitz, D. and Pielke Jr., R.A. (2005) 'Bringing society back in to the climate debate', Population and Environment, Vol. 26, No. 3, pp.255-268, doi:10.1007/s11111-0051877-6.

Rose, A. (2004) 'Economic principles, issues, and research priorities in hazard loss estimation', in Okuyama, Y. and Chang, S.E. (Eds.): Modeling Spatial and Economic Impacts of Disasters, pp.13-36, Springer Verlag, New York.

Smith, A.B. and Katz, R.W. (2013) 'US billion-dollar weather and climate disasters: data sources, trends, accuracy and biases', Natural Hazards, Vol. 67, No. 2, pp.387-410, doi:10.1007/ s11069-013-0566-5.

Smolka, A. (2006) 'Natural disasters and the challenge of extreme events: risk management from an insurance perspective', Philosophical Transactions of the Royal Society A, Vol. 364, No. 1846, pp.2147-2165, doi:10.1098/rsta.2006.1818.

Tol, R.S.J. (2003) 'Is the uncertainty about climate change too large for expected cost-benefit analysis?', Climatic Change, Vol. 56, No. 3, pp.265-289.

Toya, H. and Skidmore, M. (2007) 'Economic development and the impacts of natural disasters', Economics Letters, Vol. 94, No. 1, pp.20-25.

Tschoegl, L. (2006) An Analytical Review of Selected Data Sets on Natural Disasters and Impacts, Centre for Research on the Epidemiology of Disasters, Brussels [online] http://www.emdat.net/documents/Publication/TschoeglDataSetsReview.pdf (accessed 2 September 2014).

UNDP (2009) Guidelines and Lessons for Establishing and Institutionalizing Disaster Loss Databases, United Nations Development Programme (UNDP), Bangkok, Thailand.

UNDP/BCPR (2013) A Comparative Review of Country-Level and Regional Disaster Loss and Damage Databases New York, NY [online] http://www.undp.org/content/undp/en/home/librarypage/crisis-prevention-and-recovery/lossand-damage-database/ (accessed 2 September 2014).

UNFCCC (2011) Report of the Conference of the Parties on Its Sixteenth Session, Held in Cancum from 29 November to 10 December 2010, Part Two: Decisions Adopted by Hte Conference of Parties, 1/CP.16, Cancun, Mexico. 
UNFCCC (2012a) Report of the Conference of the Parties on Its Seventeenth Session, Held in Durban from 28 November to 11 December 2011, Part Two: Decisions Adopted by Hte Conference of Parties.

UNFCCC (2012b) A Literature Review on the Topics in the Context of Thematic Area 2 of the Work Programme on Loss and Damage: A Range of Approaches to Address Loss and Damage Associated with the Adverse Effects of Climate Change, FCCC/SBI/2012/INF.14.

UNFCCC (2013) Report of the Conference of the Parties on Its Nineteenth Session, Held in Warsaw from 11 to 23 November 2013, Warsaw, Poland [online] http://unfccc.int/resource/docs/2013/cop19/eng/10a01.pdf http://unfccc.int/meetings/warsaw_nov_2013/meeting/7649/php/view/reports.php (accessed 2 September 2014).

UNISDR (2009) Terminology [online] http://www.unisdr.org/we/inform/terminology (accessed 2 September 2014).

US Department of Commerce (2014) ESRL Global Monitoring Division - Global Greenhouse Gas Reference Network, NOAA Earth System Research Laboratory [online] http://www.esrl.noaa.gov/gmd/ccgg/trends/weekly.html (accessed 2 September 2014).

USGS (2013) 'Magnitude 9.0 - near the East Coast of Honshu, Japan', US Geological Survey [online] http://earthquake.usgs.gov/earthquakes/eqinthenews/2011/usc0001xgp/ (accessed 2 September 2014).

Wirtz, A., Kron, W., Löw, P. and Steuer, M. (2014) 'The need for data: natural disasters and the challenges of database management', Natural Hazards, Vol. 70, No. 1, pp.135-157, doi:10.1007/s11069-012-0312-4. 